\title{
BREVES REFLEXÕES SOBRE OS DEVERES FUNDAMENTAIS SOCIOAMBIENTAIS
}

BRIEF REFLECTIONS ON FUNDAMENTAL SOCIOENVIRONMENTAL DUTIES

BREVES REFLEXIONES SOBRE LOS DEBERES FUNDAMENTALES SOCIOAMBIENTALES

\section{Carlos Alberto Molinaro ${ }^{1}$}

Nicht nur die Menschheit, sondern auch jeder einzelne findet beim Erwachen zu vollen Bewußtsein eine fertige Weltansicht in sich vor, zu deren Bildung er nichts absichtlich beigetragen hat. Diese nimmt er als ein Geschenk der Natur und Kultur hin. ${ }^{2}$ Ernst Mach

1 Doutor em Direito (com registro de Doctor Europeo pela Universidade Pablo de Olavide de Sevilha- ES), revalidado pela Universidade Federal de Santa Catarina - UFSC. Mestre e Especialista em Direito Público pela PUCRS. Professor na Faculdade de Direito da Pontifícia Universidade Católica do Rio Grande do Sul (PUCRS), na Graduação e no Programa de Mestrado e Doutorado em Direito. (E-mail: carlos. molinaro@pucrs.br. URL: http://www.camolinaro.net).

2 Não só a humanidade como todo o indivíduo, ao despertar em plena consciência, já encontra pronta a visão do mundo para a qual intencionalmente não contribuiu. Toma-a, como uma dádiva da natureza e da cultura (Tradução livre). Ernst Mach, Erkenntnis und Irrtum: Skizzen zur Psychologie der Forschung. Leipzig, 1920, n. 5, p. 5. Ernst Mach (1838/1916), um dos filósofos da ciência mais originais do seu tempo, atribuiu um papel central para a imaginação na teorização científica, pois afirmava que, antes de compreender a natureza, é preciso apreendê-la em nossa imaginação, para dar um conteúdo vivo conceitos intuitivos. A intuição pode dar sentido a um cientista para um problema fundamental, ou fornecer-Ihe uma sensação para a maneira correta de resolver o enigma. A preocupação de Mach sempre foi compreender "a relação entre o pensamento cotidiano e o raciocínio científico" ( $p$. $\mathrm{XI}$ ). Erkenntnis und Irrtum é considerado um texto fundamental na psicologia da percepção e da física fisiológica para o período. No entanto, atente-se que Mach também esboçou uma psicologia conceitual diferente daquela dos seus contemporâneos, como Sigmund Freud, Hermann von Helmholtz e Gustav Fechner: a psicologia do conhecimento científico com base na capacidade da mente de conceituar. Um exame de exposições de Mach sobre a construção de teoria e análise heurística revela sua identificação inovadora do pensamento como um artefato cultural e de processos de pensamento que se correlaciona com a experiência vivida. Confira o texto on-line: www.zeno.org/Philosophie/M/Mach,+Ernst/ Erkenntnis+und+Irrtum, e obtenha gratuitamente em arquivo PDF: http://www.borders.com.au/ebook/ 
Resumo: Os deveres fundamentais são posições subjetivas ex lege. Como posições subjetivas ex lege, ora se apresentam com caráter material, como, e.g., os direitos e os deveres contidos no mandamento "preservar e restaurar os processos ecológicos essenciais", ora instrumentais, como aqueles que objetivam a execução de direitos e obrigações materiais, e.g., estudo prévio de impacto ambiental, ou com vínculos tipicamente processuais, e.g., ação popular, inquérito civil, termos de ajustamento, etc. Na dimensão objetiva, ou prestacional, sempre que não correspondam a qualquer direito subjetivo, os deveres fundamentais socioambientais, seja o destinatário o Estado, ou os particulares, revelam-se como fronteiras no exercício dos direitos. Direitos e deveres fundamentais socioambientais são importantes balizadores do poder político, notadamente o Poder do Estado, pois estes têm de respeitar os limites que the são impostos, isto é, a sujeição ao espaço de autonomia da cidadania, ou ativamente na intervenção mediante prestações específicas na conformação dos direitos e dos deveres atribuídos a essa mesma cidadania. O exposto neste ensaio, no textual e no contexto da narrativa, implicou a utillização de metódica de pesquisa no ambiro das descritivas e exploratórias, metódica essa que possibilitou uma visão ampla do tema objeto da interrogação do pesquisador.

Palavras-chave: Ambiente. Deveres. Socioambientalidade. Proteção.

Abstract: The fundamental duties are subjective positions ex lege. As such, they sometimes take on a material nature, as in, for example, the rights and duties contained in the commandment to "preserve and restore essential ecological processes"; at other times, they are instrumental in nature, as in those that focus on the execution of rights and material obligations, e.g. the prior environmental impact study, or with typically procedural links, e.g., class action, civil investigation, terms of adjustment, etc. In the objective dimension, whenever they do not correspond to any subjective rights, the socio-environmental fundamental duties, whether the addressee is the state or individuals, are revealed as borders in the exercise of rights. Social-environmental fundamental duties are important benchmarks of political power, especially 
state power, as they have to respect the limits imposed on them, i.e. the subjection of the space of autonomy of citizenship, or actively in the intervention through specific benefits in the conformation of the rights and duties assigned to that same citizenship. This essay, through its textual and narrative context, involves the use of methodical research within the framework of descriptive and exploratory, which enabled a broad view of the subject, the researcher's object of investigation.

Keywords: Environment. Duties. Socio-environmental. Protection.

Resumen: Los deberes fundamentales son posiciones subjetivas ex lege. Como posiciones subjetivas ex lege, a veces se presentan con carácter material, como, e.g., los derechos y los deberes contenidos en el mandamiento "preservar y restaurar los procesos ecológicos esenciales", otras veces instrumentales, como aquellos que tienen por objetivo la ejecución de derechos y obligaciones materiales, e.g., estudio previo de impacto ambiental, o con vínculos típicamente procesales, e.g., acción popular, averiguación civil, términos de ajuste, etc. En la dimensión objetiva o prestacional, siempre y cuando no correspondan a cualquier derecho subjetivo, los deberes fundamentales socioambientales, ya sea su destinatario el Estado o los particulares, se revelan como fronteras en el ejercicio de los derechos. Los derechos y deberes fundamentales socioambientales son importantes balizadores del poder político, particularmente el Poder del Estado, pues estos tienen que respetar los límites que le son impuestos, es decir, la sujeción al espacio de autonomía de la ciudadanía, o activamente en la intervención mediante prestaciones específicas en la conformación de los derechos y de los deberes atribuidos a esa misma ciudadanía. Lo expuesto en este ensayo, en lo textual y en el contexto de la narración, implicó la utilización de metodología de investigación descriptiva y exploratoria, metodología que posibilitó una visión amplia del tema objeto de la interrogación del investigador.

Palabras clave: Ambiente. Deberes. Socioambientalismo. Protección. 


\section{INTRODUÇÃO}

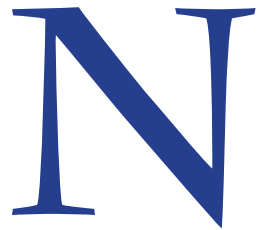

o contemporâneo de nossos dias, os problemas éticos e jurídicos atrelados aos deveres positivos gerais - principalmente no que respeita a sua fundamentação, conteúdo e perspectiva moral adquiriram uma manifesta relevância não só teórica, mas prática, em conexão, sobretudo, com os direitos e a sua implantação em vista de questões tão graves como a luta contra as desigualdades. Deveres positivos gerais são aqueles cujo conteúdo revela-se em uma ação de prestar que requer uma renúncia prosaica e cuja essência não depende da identidade do(s) obrigado(s) nem a do(s) destinatário(s) e, tampouco, é resultado de algum tipo de relação contratual prévia.

Encontra-se num mundo cuja gravidade dos problemas planetários, entre outros, os políticos, sociais, econômicos, ambientais, morais e jurídicos - exige respostas rápidas e adequadas. Para os cultores das ciências, especialmente aqueles dedicados às ciências jurídicas e sociais, impende a tarefa de construir uma perspectiva de conformação do direito ajustado a esses novos tempos, necessita-se da intuição e do sentimento na interrogação da ciência.

Não basta, apenas, pensá-lo como instrumento de pacificação dos conflitos sociais, como sistema ou ordenamento de normasjurídicas que objetivamassegurar direitos e exigir o cumprimento dos deveres, ou constituir garantias de qualquer tipo, ainda, atribuir e repartir competências e formatar o Estado; necessita-se de algo mais, é preciso refletir e pensá-lo como um processo sociocultural de regulação e garantia das conquistas obtidas mediante os indispensáveis processos de emancipação dos seres humanos, gestados no ambiente sociopolítico em que se processam relações inter-humanas que possibilitam a coexistência no presente e para as futuras gerações.

O exposto neste ensaio, no textual e no contexto da narrativa, implicou a utilização de metódica de pesquisa no âmbito das descritivas e exploratórias, metódica essa erkenntnis-und-irrtum-skizzen-zur-psychologie-der-forschung/10093717/. Há, ainda, uma reedição, em 2012, do seu Erkenntnis und Irrtum (Erweiterte Ausgabe), pela editora Jazzybee (Altenmünster, 2012) em formato de e-Book. A assertiva de Ernst Mach muito pode auxiliar-nos na construção de uma consciência plasmada nos deveres socioambientais, passar a entendê-los e concretizá-los. 
que possibilitou uma visão ampla do tema objeto da interrogação do pesquisador. Neste cenário, desenhada a narrativa, pensou-se a socioambientalidade como ponto de partida para a construção de uma reflexão sobre os deveres fundamentais de um modelo de Estado que acolhe o socioambientalismo, para proclamar-se como um Estado Socioambiental e Democrático de Direito, e que faça as necessárias conformações entre direitos e deveres, poderes e garantias, proporcionalmente distribuídos entre o Estado e a Sociedade. Para tanto, como ponto de partida, no intuito de já se delimitar nosso universo de sentido, necessária uma breve explicação sobre a utilização do adjetivo socioambiental, aliás, já incorporado na sistemática jurídico-ambiental brasileira ${ }^{3}$.

\section{SOCIOAMBIENTALIDADE E ESTADO SOCIOAMBIENTAL}

Oadjetivoé resultante do substantivo socioambientalismo (aqui um neologismo de matriz positiva, pois enriquece a língua partindo de sua própria estrutura), ou a reunião da perspectiva social e ambiental com o fundamento e objetivo da proteção dos mundos biótico e abiótico para as atuais e, especialmente, para as futuras gerações, com a integridade dos ecossistemas, o crescimento econômico e a equidade social.

A matriz socioambiental intenta construir um diálogo permanente entre necessidades sociais, exigências ambientais, crescimento ou desenvolvimento econômico possivelmente sustentável com a atribuição de um reparto dos ônus e bônus decorrentes da exploração, da apropriação e da distribuição dos bens e dos recursos naturais, desde um bem definido como conceito de Justiça Socioambiental (ou Ecológica). Contudo, uma investigação genérica sobre a temática do Estado Socioambiental é muito ampla, o que inviabilizaria a execução deste artigo, motivo pelo qual se delimitou o presente à formulação

3 No mesmo sentido cf., MOLINARO, Carlos Alberto. Pensando a Intervenção Regulatória do Sistema Jurídico nas Fases Iniciais dos Sistemas Tecnológicos em um Estado Socioambiental e Democrático de Direito. In: SILVA, Vasco Pereira da SARLET, Ingo W. (Org.) Direito Público Sem Fronteiras, Lisboa: Instituto de Ciências Jurídico-Políticas, 2011. Ainda, Interdição da retrogradação ambiental - Reflexões sobre um princípio. In: O Princípio da Proibição do Retrocesso Ambiental, Coletânea da Comissão de Meio Ambiente, Defesa do Consumidor e Fiscalização e Controle do Senado Federal. Brasília: Senado Federal, 2012. 
de bases para a construção de uma reflexão sobre os deveres fundamentais socioambientais, concretizando esta investigação por meio da aplicação, entre outros, dos princípios da precaução, da prevenção e da proibição de retrocesso socioambiental na análise da vinculação do Estado e dos particulares aos deveres fundamentais socioambientais.

A gênese do Estado Socioambiental e Democrático de Direito que formata o Estado brasileiro pode ser localizada - na perspectiva legal - na Lei $n^{\circ} 6.938$ de 31 de agosto de 1971, que construiu a Política Nacional do Meio Ambiente. Este estatuto, ademais, é considerado como o marco jurídico da normatização de interesses difusos e coletivos no Brasil e, ainda, indutor da inclusão de novos instrumentos processuais, em especial a legitimidade do MP para proposição de ação de responsabilidade civil e criminal por danos causados ao meio ambiente (art. $14, \$ 1^{\circ}$ da redação original), indução esta afinal consolidada pela Lei no 7.347/85, que cria a ação civil pública, importante instrumento processual de proteção ambiental.

No âmbito internacional, revelaram-se de grande importância as conclusões do denominado Relatório Brundtland, desenhando e defendendo o conceito de desenvolvimento sustentável (possível) desde a constatação da grave devastação ambiental, com elevado comprometimento para os recursos naturais do planeta ${ }^{4}$, questão que, vinte anos decorridos, apresenta-se como de extremada atualidade. No cenário nacional, a partir dos anos 80, especialmente com o fim do regime militar em 1984, os movimentos sociais e ambientalistas lograram com a promulgação da Constituição de 1988 - alcançar o reconhecimento de um direito fundamental ambiental que inaugura um novo modelo de Estado: o Estado Socioambiental e Democrático de Direito.

A partir da década seguinte, notadamente com a Conferência das Nações Unidas sobre o Meio Ambiente e Desenvolvimento, realizada no Rio de Janeiro em 1992 (ECO/92), os conceitos socioambientais passam a iluminar o cenário legislativo na produção de normas ambientais. A edição da Lei n 8.028 de 12 de abril de 1990, entre outras providências, acolhe e, também, modifica a Lei

4 Cf., Gro Harlem Brundtland, texto original do Report of the World Commission on Environment and Development: Our Common Future. In: http://www.un-documents.net/our-common-future.pdf. (Acesso em: 17/07/2015; 18h09m). 
no 6.938 de 31 de agosto de 1971, estabelecendo o Sistema Nacional do Meio Ambiente (SISNAMA) e instituiu o Cadastro de Defesa Ambiental. Finalmente, a Lei $n^{\circ}$ 9.985, de 18 de julho de 2000, regulamentou o Artigo 225, 1. ${ }^{\circ}$, incisos I, II, III, e VII da Constituição Federal, instituindo o Sistema Nacional de Unidades de Conservação da Natureza e outras providências.

A produção normativa subsequente foi ampla e, por vezes, confusa, o que resultou em um acentuado deficit normativo por preencher. Todavia, independente dos marcos legais, especialmente daquele estabelecido pela Carta de 1988, quando se pensa no modelo do Estado Socioambiental e Democrático de Direito, centra-se no seu princípio nuclear: o direito fundamental à vida, das presentes e futuras gerações; e a manutenção das bases que a sustentam, imperativo que só se concretiza num ambiente equilibrado e saudável, realizando o núcleo duro da relação de alteridade que está implicada no conceito de dignidade humana: não se está só, somos com o outro numa relação permanente de reconhecimento, respeito, reciprocidade e responsabilidade que se desenvolve num espaço e tempo de encontro: o ambiente.

\section{O AMBIENTE COMO DIREITO E A DIMENSÃO HORIZONTAL DO DEVER DE PROTEÇÃO E PRESERVAÇÃO}

Em matéria de direito ambiental, a correlação entre direitos e deveres fundamentais é, ainda, pouco divulgada, acrescente-se, também, o fato de que a matéria relativa aos deveres fundamentais (e também aos deveres humanos fundamentais) ainda não foi objeto de consideração mais aprofundado pelos tribunais, e pela doutrina nacional e mesmo estrangeira, sendo poucos os trabalhos monográficos a eles dedicados, especialmente o tocante aos identificados como deveres fundamentais autônomos ${ }^{5}$.

Na perspectiva dos deveres fundamentais socioambientais, e já tomando como referência o significado do conceito de Estado Socioambiental, cita-se o art. 225 da Carta de 1988, que ocupa topo central no espaço jurídico ambiental ao dispor:

5 Sobre deveres autônomos, consulte o excelente trabalho de CASALTA NABAIS, Jose, O Dever Fundamental de Pagar Impostos. Lisboa: Almedina, 2009. 
Todos têm direito ao meio ambiente ecologicamente equilibrado, bem de uso comum do povo e essencial à sadia qualidade de vida, impondo-se ao Poder Público e à coletividade o dever de defendê-lo e preservá-lo para as presentes e futuras gerações.

Do texto constitucional fica bem esclarecido que o ambiente é um direito atribuído a um sujeito plural sobre bem de uso comum. Como res communes omnium é um bem público com um qualificado predicado: atemporalidade. De outro modo, perspectivado como totalidade atributiva ${ }^{6}$, caracteriza-se como um macrobem que não se confunde com os bens que o incorporam ${ }^{7}$. Ademais, é insusceptível de apropriação, também indisponível, indivisível, imaterial e de titularidade difusa.

O ambiente, como um bem, salienta Herman Benjamin, revela-se como um bem público em sentido objetivo e não subjetivo ${ }^{8}$, fundado em um interesse difuso, o que oportuniza a dimensão horizontal e vertical do dever de proteção e preservação: Estado e Sociedade, ademais dos sujeitos de direito entre si mesmos. Nesse sentido, para assegurar este direito são, entre outros, deveres do Estado:

a) preservar e restaurar os processos ecológicos essenciais e prover o manejo ecológico das espécies e ecossistemas (Art. 225, §1ํㅣ I da CF/88 c/c a Lei no 9985/2000 e MP n 366 de 26/04/2007);

b) preservar a diversidade e a integridade do patrimônio genético do País e fiscalizar as entidades dedicadas à pesquisa e manipulação de

6 As totalidades atributivas são aquelas cujas partes estão referidas umas com as outras, seja simultaneamente, seja sucessivamente e, mais, suas conexões atributivas não implicam inseparabilidade.

7 Cf. BENJAMIM, Antônio Herman V. Função ambiental. In: Dano ambiental: prevenção, reparação e repressão. São Paulo: Revista dos Tribunais, 1993, p. 66-69. Cf., ainda, SOUZA FILHO, Carlos F. Marés. O dano socioambiental e sua reparação. In: FIGUEIREDO, Guilherme J. Purvin de (Coord.). Direito Ambiental em debate. Rio de Janeiro: Esplanada, 2004, p.67-75. Cf., também, LEITE, José R. Morato; AYALA, Patryck de Araújo. Novas Tendências e Possibilidades do Direito Ambiental no Brasil, em WOLKMER, Antonio Carlos; LEITE, José Rubens Morato (Org.). Os Novos Direitos no Brasil: Natureza e Perspectivas. 1. ed. São Paulo: Saraiva, 2003, v., p. 181-292: "[...] Com efeito, desta forma, visualiza-se o meio ambiente como um macrobem, que além de bem incorpóreo e imaterial se configura como bem de uso comum do povo. Isso significa que o proprietário, seja ele público ou particular, não poderá dispor da qualidade do meio ambiente ecologicamente equilibrado, devido à previsão constitucional, considerando-o macrobem de todos. Adita-se, no que se refere à atividade privada, a qualidade do meio ambiente deve ser considerada, pois o constituinte diz que a atividade econômica deverá observar, entre outros, o princípio da proteção ambiental, conforme estatui o art. 170, VI, da Constituição da República Federativa do Brasil. [...]" (p. 216).

8 BENJAMIM, Antônio Herman V. Função ambiental. In: Dano ambiental: prevenção, reparação e repressão. São Paulo: Revista dos Tribunais, 1993, p. 66. 
material genético (Art. 225, §1${ }^{\circ}$ II da CF/88 c/c a Lei nº 9985/2000, a Lei $n^{\circ} 11105 / 2005$, e a Lei no $\left.11460 / 2007\right)$;

c) definir, em todas as unidades da Federação, espaços territoriais e seus componentes a serem especialmente protegidos, sendo a alteração e a supressão permitidas somente através de lei, vedada qualquer utilização que comprometa a integridade dos atributos que justifiquem sua proteção (Art. 225, §1º, III da CF/88 c/c a Lei nº 9985/2000);

d) exigir, na forma da lei, para instalação de obra ou atividade potencialmente causadora de significativa degradação do meio ambiente, estudo prévio de impacto ambiental, a que se dará publicidade (Art. 225, §1º, IV da CF/88 c/c a Lei nº 9985/2000);

e) controlar a produção, a comercialização e o emprego de técnicas, métodos e substâncias que comportem risco para a vida, a qualidade de vida e o meio ambiente (Art. 225, §1 ${ }^{\circ}$, V da CF/88 c/c a Lei $n^{\circ}$ 9985/2000);

f) promover a educação ambiental em todos os níveis de ensino e a conscientização pública para a preservação do meio ambiente (Art. 225, §1, VI da CF/88 c/c a Lei nº 9795/1999 e o Decreto nº 4281 de 25/06/2002);

g) proteger a fauna e a flora, vedadas, na forma da lei, as práticas que coloquem em risco sua função ecológica, provoquem a extinção de espécies ou submetam os animais a crueldade (Art. 225, §1, VII da CF/88 c/c a Lei n 9985/2000, com o Decreto nº 4340 de 22/08/2002).

A ação verbal de restaurar, preservar, definir, exigir, controlar, promover e proteger implica transitividade, isto é, não permanece indefinidamente, necessita de permanente complemento, ou recriação e revigoramento, o que se alcança com o permanente cumprimento dos deveres inerentes.

A Constituição brasileira, desta forma, privilegia uma estrita modalidade de posições jurídicas, pois ou são direitos-deveres (ou deveres-direitos pendentes à posição do sujeito) de proteção, articulando os direitos subjetivos de sujeitos singulares e plurais e, na esfera pública, tarefas, objetivos, sujeições e deveres de proteção do Estado. É neste sentido que os direitos-deveres socioambientais são 
direitos e deveres fundamentais e, como tais, gozam de tratamento privilegiado na ordem constitucional e nos tratados internacionais, albergados pelo ordenamento jurídico brasileiro.

No espaço constitucional pode-se encontrá-los de modo implícito ou explícito. Explicitamente são aqueles referidos expressamente no art. 225 da Constituição de 1988; ao contrário, os implícitos são irradiações ou decorrências da proteção ambiental, pois incorporam, além de os assegurarem, os atos de valoração ambiental, como o direito à vida, à saúde, à propriedade, à informação, à cultura, à educação e ao exercício das ações constitucionais, entre outros. Logo se pode falar de deveres socioambientais na dimensão objetiva e subjetiva, pois ora exigem a inação, ora a efetiva prestação dos seus destinatários.

\section{OS DEVERES FUNDAMENTAIS NO MARCO DO ESTADO SOCIOAMBIENTAL E OS PRINCÍPIOS DE DIREITO AMBIENTAL}

Os deveres fundamentais são posições subjetivas ex lege, pois ao contrário dos direitos e dos deveres humanos quando compreendidos como processos culturais emancipatórios de contendas para a concretização da dignidade humana, sempre derivam do direito objetivo.

Como posições subjetivas ex lege, ora se apresentam com caráter material, como, e.g., os direitos e os deveres contidos no mandamento "preservar e restaurar os processos ecológicos essenciais", ora instrumentais, como aqueles que objetivam a execução de direitos e as obrigações materiais, e.g., estudo prévio de impacto ambiental, ou com vínculos tipicamente processuais, e.g., ação popular, inquérito civil, termos de ajustamento, etc. ${ }^{9} \mathrm{Na}$ dimensão objetiva, ou prestacional, sempre que não correspondam a qualquer direito subjetivo, os deveres fundamentais socioambientais, seja o destinatário o Estado, ou os particulares, revelam-se como fronteiras no exercício dos direitos.

Direitos e deveres fundamentais socioambientais são importantes balizadores do poder político, notadamente o Poder do Estado, pois estes têm de respeitar 9 Cf. BENJAMIN, Antônio Herman V. Crimes contra o meio ambiente: uma visão geral. In: Ministério Público e Democracia - Livro de teses. Fortaleza: CONAMP, 1998. T. 2, p. 28-29. 
os limites que Ihe são impostos, isto é, a sujeição ao espaço de autonomia dos cidadãos e das cidadãs, ou a ativamente na intervenção mediante prestações específicas na conformação dos direitos e dos deveres atribuídos a esses mesmos cidadãos e cidadãs. É neste locus discursivo que se revela o tema da eficácia dos direitos e dos deveres fundamentais sociais e ambientais, que podem ser perspectivados desde diferentes notações, segundo a intensidade normativa de cada um desses direitos e deveres. Aí se insere a dissensão entre normas constitucionais preceptivas e normas constitucionais programáticas, com as consequentes resultantes que operam em ambas as espécies normativas, isto é, uma intervenção reguladora; e uma intervenção restritiva.

Sabidamente, e aí há consenso doutrinário, a força diretiva dos direitos, das liberdades e das garantias é mais robusta que aquela atribuída aos direitos econômicos, sociais, culturais e ambientais (DESCA), e isto vai se refletir, especialmente, na perspectiva material e na organizatória desses direitos, pois a intensidade de restrição nos primeiros é bastante limitada, e na perspectiva organizatória sempre haverá submissão à reserva parlamentar, contrariamente ao que ocorre com os últimos, que possuem menor força diretiva, o que tem reflexos imediatos no tema dos deveres.

Relativamente aos deveres socioambientais fundamentais está para ser construída uma deontologia socioambiental. Aí, ingressa-se no fértil terreno das obrigações diretamente implantadas pelolegislador, com destinatários específicos, sejam sujeitos singulares ou plurais, seja a coletividade como identidade, seja o Estado ou seus agentes políticos.

Neste espaço deontológico toma lugar de destaque um dever geral de não degradar, de não contaminar, com toda a irradiação das obrigações pertinente, como explicitado no art. 225, parágrafo $1^{\circ}$ da Carta de 1988. Aliás, este dever central talvez tenha sido inspirado pelo que já estava bem definido no art. 29 da Declaração Universal de $1948^{10}$. Agora, um renovado dever-direito, cuja dimensão da obrigação avulta na proteção socioambiental justamente para tornar possíveis as atribuições de direitos e torná-los concretos.

10 Declaração Universal dos Direitos Humanos, Artigo XXIX. 1. Todo ser humano tem deveres para com a comunidade, na qual o livre e pleno desenvolvimento de sua personalidade é possível. 
O direito-dever fundamental ambiental está informado por muitos princípios que a doutrina vem afirmando com grande insistência, cuja revelação a ciência jurídica e os pretórios vêm aperfeiçoando. São princípios decorrentes, na sua maioria, da amplitude do tipo contido no artigo 225, incisos e parágrafos da Constituição de 1988, combinados com outras normas constituídas na mesma Carta, e em Tratados e Convenções por ela recepcionados, ademais do conjunto normativo infraconstitucional pertinente ${ }^{11}$.

Sabe-se que o direito de cada sujeito, singular ou plural, a um ambiente ecologicamente equilibrado não constitui per se um direito subjetivo susceptível de apropriação. A atribuição que aí está é de permissão que exige um dever fundamental consubstanciado na utilização racional desde uma perspectiva de fraternidade ou solidariedade, seja na atualidade, seja com as gerações vindouras.

Este dever é de todos e de cada um individualmente, inclusive, por constitucionalmente expresso, do Estado ${ }^{12}$.

11 O conjunto normativo ambiental está construído através de proposições empíricas especialíssimas. No percurso de seu desvelamento e submetidas a racionalidade prática essas proposições se incorporaram em uma série de princípios, ditos princípios ambientais que se positivaram e, de modo não exaustivo, podem assim ordenar-se: Princípio constitucional de proteção ambiental (CF/88, Art. 225). Princípio da legalidade (CF/88, Art. 5, II). Princípio da supremacia do interesse público primário e princípio da indisponibilidade do interesse público (CF/88, art. 225), temperado pela observância dos direitos fundamentais e das normas programáticas a eles referidas. Princípio da obrigatoriedade da proteção ambiental (idem). Princípio da prevenção e princípio da precaução (CF/88, 225, § 1, IV; Dec. Rio/1992, princípio (15). Princípio da obrigatoriedade de avaliação prévia de obras potencialmente gravosas (CF/88, 225; EIA, RIMA). Princípio da publicidade (CF/88, 225; Res. 9 do CONAMA). Princípio da reparabilidade do dano ambiental $(\mathrm{CF} / 88,225$, § 3; L. 6938, art. 4, VII). Princípio da participação (Declaração Rio/92, princípio 10; CF/88, 225). Princípio da informação (CF/88, 225; 216, § 2; L. 6938/81; Dec. 98161/89; L. 8078/90 [CDC]; Agenda 21, cap. 40; e as convenções sobre Diversidade Biológica e Combate a Desertificação). Princípio da função socioambiental da propriedade (CF/88, art. 5, XXIII, 170, III e 186, II). Princípio do poluidor-pagador (CF/88, art. 225, § 3; Rio/92, princípio 16; L. 6938/81, art. 4; L. 9433/97). Princípio da compensação (art. 8, L. 6938/81, atrib. CONAMA). Princípio da responsabilidade (L. 9605/98, crimes ambientais; L. 6938/81 art. 14, responsabilidade objetiva do degradador). Princípio do desenvolvimento sustentável (Declaração Rio/92, princípio 13, e Agenda 21). Princípio da educação ambiental (CF/88, art. 1; e, Agenda 21). Princípio da cooperação internacional (Declaração Rio/92, princípio 2). Princípio da soberania dos Estados na política ambiental (Agenda 21). Princípio da Prevenção de danos, aqui cabe uma distinção: princípio da prevenção e princípio da precaução. A distinção está na natureza do risco, v.g., CF/88, art. 7.o XII prevê: "a redução dos riscos inerentes ao trabalho, por meio de normas de saúde, higiene e segurança". Aplica-se o preceito constitucional ao cuidado da prevenção ou precaução. Tudo está na natureza do risco. Sendo o núcleo duro na prevenção, o perigo concreto; na precaução, o perigo abstrato. Em ambos os casos, o meio ambiente do trabalho deverá contar com as condições necessárias para minimizá-lo, e contar o trabalhador com a proteção adequada, mesmo a compensação argentária.

12 Atente-se que Robert ALEXY entende o ambiente numa perspectiva de holodimensão, de "direito fundamental como um todo" (Teoría de los derechos fundamentales. Trad. de Ernesto Garzón Valdés. Madrid: Centro de Estudios Políticos y Constitucionales, 3. ${ }^{a}$ reimp. 2002, p. 240-245), vale dizer, um 
Veja-se que o tipo constitucional do art. 225 encerra um objetivo composto: ambiente equilibrado e bem de uso comum, essencial para a qualidade de vida, e deveres recíprocos do Estado e da coletividade. Nada aí configura um direito subjetivo, mas confirma um dever de preservação para a atualidade e para o porvir. Revelando-se, então, um dever-direito fundamental acrônico, cujo núcleo duro está na vedação da degradação ambiental, objeto do princípio, sob pena de defraudar-se o conceito.

No entanto, é certo que grande parte da doutrina já se inclinou pela atribuição de um direito subjetivo negativo. Com todo o respeito, não se pensa assim. Devese entender que o ambiente é um bem da coletividade ${ }^{13}$, aí reside seu núcleo duro, portanto não pode servir a uma perspectiva individualista, sua própria matriz ancorada na solidariedade o informa como dever-direito ao ambiente ecologicamente equilibrado, bem como defendê-lo e preservá-lo.

A mais de ser um dever, ele é diretamente derivado do princípio do Estado Social e Democrático de Direito, que se insere no sistema jurídico objetivado. Nestes aspectos que se fundamenta a importância de um estudo mais aprofundado sobre os deveres fundamentais, notadamente no tocante ao desenvolvimento de novas ideias sobre deveres objetivos e subjetivos, relacionado à teoria dos deveres de proteção.

Entretanto, para que nosso empreendimento seja ainda mais específico, propõe-se dar um foco ainda mais objetivo, tomando como norte de orientação dessas reflexões os princípios da precaução e da prevenção, como se explicitará objeto complexo e de estrutura definida: "as distintas posições do cidadão e do Estado, e entre estas posições existem relações claramente determináveis, as relações de precisão, de meio/fim e de ponderação" (p. 245). Mais adiante, afirma ALEXY: "Está constituído por um feixe de posições de tipos muito diferentes. Assim, quem propõe o estabelecimento de um direito fundamental ambiental ou sua adiscrição interpretativa às disposições iusfundamentais existentes pode, por exemplo, incluir neste feixe um direito a que o Estado se omita de determinadas intervenções no meio ambiente (direito de defesa), um direito a que o Estado proteja o titular de direito fundamental frente a intervenções de terceiros que danifiquem o ambiente (direito de proteção), um direito a que o Estado permita participar o titular de direito em procedimentos relevantes para o meio ambiente (direito ao procedimento) e um direito a que o próprio Estado realize medidas fáticas tendentes a melhorar o ambiente (direito a uma prestação fática)" (p. 429); concluindo o ilustre jurista que essas posições tratam-se como direitos prima facie ou como direitos definitivos.

13 José Rubens MORATO LEITE o denomina de um macrobem (Cf. LEITE, J. R. M., Dano Ambiental: do individual ao coletivo extrapatrimonial. 2. ed. rev., atual., ampl. São Paulo: Editora Revista dos Tribunais, 2003, p. 81-85), uma concepção que conduz o nosso olhar para uma dimensão holística, um ver estético que apreenda toda sua totalidade. 
a seguir, pois é importante para o intento a análise do princípio de proteção do mínimo existencial ecológico e o da proibição de retrocesso ambiental, pois são, entre outros, princípios de justificação de um Estado Socioambiental e Democrático de Direito e estão subjacente na tríade principial ${ }^{14}$ (Prinzipientrias): o princípio da precaução (Vorsorgeprinzip); o princípio da responsabilidade pela causa, isto é, o princípio do poluidor pagador (Verursacherprinzip) ${ }^{15}$; e o princípio de cooperação

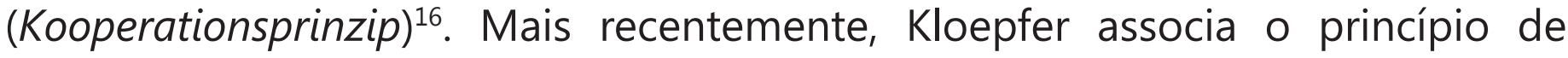
integração (Integrationsprinzip) ${ }^{17}$, podendo-se inferir, então, a existência de treta princípios de justificação.

Nesta linha, o princípio da precaução acolhe a máxima in dubio pro ambiente $^{18}$, sendo um dos mais importantes princípios de proteção ambiental. Aproxima-se e inclui o princípio da cautela, ou prudência (Vorsichtsprinzip ${ }^{19}$ ) como atuação preventiva (Verhütungsmassnahme) frente a potenciais riscos de contaminação do meio ambiente ${ }^{20}$. Sua origem está no direito alemão dos anos setenta; amadureceu no encontro das Nações Unidas em Estocolmo em 1972 e obteve consagração na Conferência Rio/92 que propôs a seguinte definição:

O Princípio da Precaução é a garantia contra os riscos potenciais que, de acordo com o estado atual do conhecimento, não podem ser ainda identificados. Este Princípio afirma que a ausência da certeza científica formal, a existência de um risco de um dano sério ou irreversível requer a implementação de medidas que possam prever este dano.

No Brasil foi introduzido pela Lei $n^{\circ}$ 6.938/81; tendo sido acolhido na Constituição de 1988 no inciso IV do artigo 225; sendo objeto de tipificação penal pela Lei dos Crimes Ambientais (Lei n 9605/98) no seu artigo 54, § 3.

14 Neologismo, adjetivação do substantivo "princípio" com o sufixo "-al", indicando um coletivo de princípios.

15 Subsistema de responsabilidade de suportar um dever ambiental.

16 Cf. KLOEPFER, M. Umweltrecht. 3. ed. Munique: Beck Juristischer Verlag, 2004, p. 168 e ss., principalmente pp. 173, 185, 189 e ss., especialmente p. 193 (Umweltpolitiche Funktion); p, 198.

17 Cf. KLOEPFER, M. Umweltrecht. 3a ed. Munique: Beck Juristischer Verlag, 2004 p. 204.

18 Cf. CANOTILHO, J. J. G. Direito Público do Ambiente. Coimbra: Faculdade de Direito de Coimbra, 1995, p. 40.

19 Vorsichtsprinzip, princípio da cautela, ou princípio da prudência, tomado de empréstimo das ciências das finanças e do direito comercial alemão (cf. § 252, do Handelsgesetzbuch - HGB), em direito ambiental pode-se entendê-lo como princípio da prevenção.

20 Cf. KLOEPFER, M. Umweltrecht. 3. ed. Munique: Beck Juristischer Verlag, 2004, p. 179. 


\section{Como norma de sobredireito, diz o Princípio 15 da Declaração do Rio/92:}

Princípio 15: De modo a proteger o meio ambiente, o princípio da precaução deve ser amplamente observado pelos Estados, de acordo com suas capacidades. Quando houver ameaça de danos sérios ou irreversíveis, a ausência de absoluta certeza científica não deve ser utilizada como razão para postergarmedidas eficazes eeconomicamente viáveis para prevenir a degradação ambiental.

\section{Cumpre notar que toda a abordagem com assento no princípio da precaução} (Vorsorgeprinzip) deve ter em conta o princípio da prevenção (Vorsichtsprinzip ${ }^{21}$ ), ou prudência frente ao perigo de determinados eventos que podem gerar danos consideráveis ou mesmo irreversíveis ao ambiente (in dubio pro securitate), especialmente frente às incertezas científicas.

Aqui uma distinção se impõe: (a) princípio da precaução e (b) princípio da prevenção que o direito alemão distingue da precaução ${ }^{22}$ quanto a sua finalidade e utilização como prevenção (vigilância) ou providência; em (a) o núcleo duro está num risco potencial, já em (b) o que se objetiva é obstaculizar um risco conhecido por meio de uma medida preventiva (Verhütungsmassnahme). Ambos os princípios, precaução e prevenção, a toda evidência, são corolários dos princípios de proteção do mínimo existencial ecológico e da vedação da degradação, pois eles representam uma garantia na manutenção do status quo socioambiental.

21 Vorsichtsprinzip, princípio da cautela, ou princípio da prudência, tomado de empréstimo das ciências das finanças e do direito comercial alemão (cf. § 252, do Handelsgesetzbuch - HGB), em direito ambiental podemos entendê-lo como princípio da prevenção.

22 Ao se estudar o direito ambiental alemão, deve-se ler com atenção o emprego do substantivo Vorsorge (precaução), distinguindo-o dos substantivos Vorbeugung (prevenção propriamente dita, ou no sentido profilaxia, ou de ação preventiva), ou Vorbeugunsgrundsatz (aqui como equivalente ao Vorsorgeprinzip) e Vermeidung (prevenção no sentido de evitar um dano, ou em português: evitação, isto é, ato de evitar algo especialmente desagradável. [Cf. CREIFELDS et all. Rechtswörterbuch. München: Beck, 2007]). A legislação utiliza os termos nas mais diversas circunstâncias, e.g., Lissabon-Vertrag, (Dritter Teil - Die internen Politiken und Maßnahmen der Union (Art. 26 - 197), Titel XX - Umwelt (Art. 191 - 193): art. 191 [...] Die Umweltpolitik der Union zielt unter Berücksichtigung der unterschiedlichen Gegebenheiten in den einzelnen Regionen der Union auf ein hohes Schutzniveau ab. Sie beruht auf den Grundsätzen der Vorsorge und Vorbeugung, auf dem Grundsatz, Umweltbeeinträchtigungen mit Vorrang an ihrem Ursprung zu bekämpfen, sowie auf dem Verursacherprinzip. (A política da União no domínio do ambiente terá por objetivo atingir um nível de proteção elevado, tendo em conta a diversidade das situações existentes nas diferentes regiões da União. Basear-se-á nos princípios da precaução e da ação preventiva, da correção, prioritariamente na fonte, dos danos causados ao ambiente e do princípio do poluidor-pagador. Tradução livre), in: http://dejure.org/gesetze/AEUV/191.html. Cfr. ainda, Bundes-Immissionsschutzgesetz - BImSchG, em vários artigos, especialmente sobre o dever de precaução (Vorsorgepflicht) no § 5 (1), 4; in: http://www.gesetze-im-internet.de/bimschg/BJNR007210974.html. 


\section{O princípio do poluidor-pagador (Verursacherprinzip), encadeamento dedutivo} da responsabilidade causal, objetiva a absorção dos custos externos da degradação ambiental, por isso tem uma racionalidade econômica embutida muito importante em política ambiental, pois persegue a internalização das externalidades negativas provocadas pelos processos de poluição ambiental. A propósito, objetivando a correção dessas externalidades, surgiram teorias de economia ambiental23, sendo muito relevante o denominado "teorema de Coase"24.

23 Cf. KLOEPFER, M., Umweltrech. 3. ed. Munique: Beck Juristischer Verlag, 2004 p. 191 e s.

24 Em 1960, Ronald COASE (The problem of social cost, Journal of law and economics, l-44, outubro de 1960, Univ. of Chicago Press) apresenta uma proposta analítica ao tratar do postulado keynesiano no sentido que as externalidades deveriam ser internalizadas pela intervenção do Estado, por meio da imposição tributária-fiscal aos agentes causantes, e beneficiários de dita externalidade; COASE acreditava que a solução das externalidades não devia se dar pela intervenção do Estado no mercado, ao contrário, deveria provir da radicalização de soluções exclusivamente mercantis. Sua proposta acabou cunhada por STIGLER - de TEOREMA DE COASE, que pode ser formulado do seguinte modo: "em um mercado equilibrado, onde existam condições de competência perfeita, e na ausência de custos de transações, as partes encontrarão uma solução eficiente". A dedução consequente no Direito está centrada em garantir que funcione um modelo de competência perfeita, isto é, deve reduzir a existência de falhas no mercado, como as externalidades (COASE não fala em "externalidades", ele denomina "efeitos externos". O conceito de externalidade ou efeito externo revela-se como o benefício ou prejuízo atribuído a um agente econômico (seja consumidor ou empresa) como consequência do ato de produção ou consumo de outro. Assim o atingido da externalidade pode ser um consumidor ou um produtor e o causador da mesma. Esses efeitos externos podem ser benéficos, externalidades positivas, ou danosos caso em que se denominam de externalidades negativas, as mais habituais neste âmbito, os monopólios, e garantir as condições de liberdade e segurança; vale dizer: reduzir os custos de transação. Quando não é possível reduzir os custos de transação, e esses se tornam tão altos que dificultam uma solução de mercado, cabe ao Direito prover uma solução, contudo, esta deve estar fundada numa lógica que reproduza, o mais aproximadamente possível, o que fariam dois sujeitos negociando livremente. Atentese que, como qualquer teorema, algumas premissas devem ser observadas, são elas: (a) ausência de custos de transação; (b) direitos de propriedade bem definidos (muitos autores criticam a necessidade de individualizar um direito); (c) pequeno número de sujeitos. Atendidas essas, o resultado indicará que sempre se alcança o ótimo (paretiano) independentemente de qual sujeito seja o titular dos direitos de propriedade. Coase, de um lado, postulava que se devia entender, externalidades (efeitos externos) como um problema de responsabilidade unidirecional - já que relativos a uma recíproca questão entre os atores - dos impactos e custos relacionados; de outro, propugnava que a eliminação dos custos de transação - própria da intervenção estatal - se desse entre os sujeitos envolvidos mediante um acordo negociado entre eles, objetivando a máxima rentabilidade possível. Ocorre que Coase pensava que um acordo negociado no mercado pelas partes envolvidas, em igualdade de condições e sem custos institucionais, vale dizer, tributos de qualquer espécie, tem como consequência um incremento da eficiência, resultando em maior rentabilidade total. Para tanto, acreditava ser necessário que o sistema legal atribuísse claramente os direitos de propriedade (atente-se que se deve traduzir o inglês property rights em um contexto amplo, com o significado mais abrangente, que simplesmente direitos de propriedade, isto é, direitos de apropriação, no sentido da "pertença" que se atribui; o exemplo clássico, de que falam os autores, está no sentido que, quando uma empresa está autorizada a pôr seus dejetos em determinado lugar, e.g., um rio, não é a mesma proprietária do rio, contudo, tem um "direito de apropriação", sobre aquele espaço para dispor seus dejetos) de forma tal que, todo o titular que possa afetar ou ser afetado pelas atividades econômicas, seja efetivamente um proprietário claramente definido. Só deste modo, o sistema de preços do mercado tem condições de indicar com precisão e eficientemente quem são os agentes e quais são os interesses (custos e benefícios) que devem ser estimados. 
Contudo, o que Coase propunha é que todos os efeitos externos podem ser internalizados eficientemente e otimamente para o produto líquido total, por meio do estabelecimento de direitos de propriedade (direitos de apropriação) e a negociação dos atores, neste cenário do mercado - via um sistema de preços - em competência equilibrada, perfeita e sem custos de transação.

O mais importante é se saber que Coase estava consciente de que toda a atribuição de direitos é essencial para a eficiência dos sistemas econômicos sempre que os custos de transação são elevados, e por isso mesmo não titubeava em afirmar e apoiar as reordenações judiciais desses, de modo a permitir uma melhora no valor global da produção.

Uma crítica simplificada que se pode fazer está em que se deve entender que a simples substituição de um modelo de causalidade por um de reciprocidade, per se, revela-se insubsistente, pois quando dita substituição é realizada, na verdade o que se faz é alterar a causa eficiente para uma teleológica.

Note-se, que não se encontra nos direitos e nas liberdades a causa determinante da natureza da responsabilidade, mas nos resultados finais de um objetivo teleológico, último, no dizer de Coase, "a maximização da produção".

O que se vê, então, é a comutação da responsabilidade pela finalidade, ou por outra, a causalidade pela teleologia produtivista. O valor "maximização da produção" é um valor heterônomo ao valor ético e se pode dizer imanente à lógica da produção, pois "maximizar" por "maximizar" se converte num performativo que induz a conclusão que afirma: a legitimação da ação se concretiza na efetividade da ação mesma.

Ora, isto leva a concluir que deverá prevalecer toda a ação (que não é senão um direito de propriedade em exercício) ou a articulação de ações (negociação) que induza como resultado um tautológico "melhor resultado", desde o critério da maximização.

A consequência mais imediata, é que esta causalidade teleológica reduz todo o direito ao direito de propriedade, de outra parte, reduz toda a liberdade à liberdade de mercado (quando Coase exemplifica com o caso que, frente a um 
fábrica poluente, os vizinhos se mudem de lugar, deixando seus terrenos para a fábrica, tendo em conta os custos mais baratos, para a fábrica, na transladação e na alocação desses vizinhos para outro espaço urbano, do que o de mover a fábrica está empregando um princípio de causalidade teleológica produtivista com fundamento numa ética performativa).

O que Coase não leva em consideração são os motivos dos vizinhos, valores que sua tese despreza como: significações valorativas culturais, étnicas, urbanísticas, afetos, etc. $\mathrm{O}$ argumento de que esses motivos se podem traduzir em expressão monetária não convence. Por óbvio, se convertidos, eles vão formar parte dos fatores de produção final, mas se indaga: se pode expressar tudo por meio de um preço?). O que Coase refuta é a tese pigouniana, muito cara aos economistas do bem-estar, entre a tensão dialética: custos privados e custos sociais. São estes últimos, segundo Pigou ${ }^{25}$, os que justificam a intervenção reguladora do Estado no mercado.

Finalmente, uma crítica importante está em que, para que efetivamente tenha resultado a negociação entre os atores, é necessário que o procedimento da negociação entre eles não tenha custos associados. Portanto, o sistema só implica aplicabilidade quando o número de atores (agentes) envolvidos no cenário negocial é reduzido, e na medida direta da nulidade ou residualidade dos custos de transação.

Assim, toda teoria econômica em direito ambiental precisa ser lida com cautela, pois o princípio de responsabilidade causal de que deriva o princípio do poluidor-pagador representa, como diz Ramón Martin Mateo, um sólido fundamento para a política e o direito ambiental e sua concretização está na eliminação das motivações econômicas da contaminação ambiental, desde uma perspectiva de uma ética distributiva ${ }^{26}$.

Observe-se, especialmente, ensina Kloepfer, que o princípio do poluidor pagador (Verursacherprinzip) deve ser entendido como princípio de responsabilidade

25 PIGOU, Arthur C. (1932). The Economics of Welfare. London: Macmillan and Co. [ed. orig.: 1920]. Versão eletrônica, http://www.econlib.org/library/NPDBooks/Pigou/pgEWCover.html.

26 MARTIN MATEO, R. Manual de derecho ambiental. Madrid: Trivium, 1995, p. 55 
(Verantwortungsprinzip) efetiva ${ }^{27}$. Estes princípios, certamente, são importantíssimos para a concreção do mínimo existencial ecológico e para a vedação do retrocesso, pois desde a efetiva responsabilização se aproxima uma justiça ambiental das condições fáticas ambientais que reclamam, no plano político e jurídico, correção de injustiças sociais - resultante de encargos para a sociedade não incluídos nas decisões de produção ou de consumo por parte dos agentes contaminantes ${ }^{28}$.

Relativamente ao princípio de cooperação (Kooperationsprinzip) e ao princípio de integração (Integrationsprinzip), serão referidos brevemente. Ambos, por óbvio, estão em consonância com a manutenção de um mínimo existencial ecológico e com a garantia de proteção contra a retrogradação ambiental.

O princípio de cooperação está conformado por dois imperativos: a responsabilidade e a distribuição dos deveres entre o Estado e a sociedade, entendidos estes como uma comunhão perceptiva dos encargos que a conservação e a manutenção do ambiente exigem ${ }^{29}$; está, também, suportado pelo princípio da participação democrática que envolve a todos, pois forte na ideia que os graves problemas ambientais têm de que ser enfrentados entre o Estado e a sociedade conjuntamente, por meio dos diversos grupos e atores sociais, Ihes garantindo não apenas a participação nas decisões, mas também, e de maneira especial, a possibilidade de formular e executar políticas ambientais.

Oprincípio da cooperação-fundado na participação todosaqueles relacionados ao ambiente - exige para a sua concretização consenso dos diversos Estados e organizações internacionais, pois o ambiente como "lugar de encontro" dos seres e das coisas não obedece a fronteiras normativas, espaciais ou temporais ${ }^{30}$. No direito interno brasileiro, vale lembrar a Lei no 9985, de 2000, que regulamentou o artigo 225, § $1^{\circ}$, incisos I, II, III E VII, da Constituição de 1988, e instituiu o sistema nacional de unidade de conservação da natureza (SNUC - que está formado pelo conjunto das unidades de conservação federais, estaduais e municipais).

27 Cf. KLOEPFER, Grundprinzipien..., p. 9

28 Cf. CANOTILHO, J. J. G., Direito público..., p. 43

29 Cf. KLOEPFER, M., Umweltrecht..., p. 198 e s.

30 Nesse sentido o art. $174^{\circ}, \mathrm{n}^{\circ} 4$, do Tratado CE, dispõe que, no domínio do meio ambiente, a Comunidade e os Estados-membros cooperarão, no âmbito das respectivas atribuições, com os países terceiros e as organizações internacionais competentes. 
O princípio de integração (Integrationsprinzip) revela-se num princípio de equilíbrio entre meios adequados de políticas de crescimento econômico e social, bem como diretrizes jurídicas socioambientais para a conservação do entorno com o objetivo de desenvolvimento integrado, coerente e, aí sim, sustentável.

Deste princípio, numa perspectiva holística, são constituídos critérios de decisão que não podem ser de ordem estritamente econômica, bem como não podem ser de ordem exclusivamente ambientalista, apostando pela integração das diversas políticas com o objetivo de uma justa composição dos vários interesses envolvidos na questão ambiental. Este princípio enfoca toda a proteção ambiental, não se impondo cortes entre contaminação das águas, solos ou emissões poluentes na atmosfera; de outro modo, esta integração incorpora duas dimensões, uma externa, conformada na jurisdição internacional, e outra interna, relativa ao limite da jurisdição nacional ${ }^{31}$; no plano interno, dele decorre o princípio de unidade de gestão e ação, pois a responsabilidade pela política ambiental e sistematização ambiental do território fica integradamente distribuída ente os agentes públicos e privados encarregados do planejamento econômico e social integrados na política ambiental.

O princípio da integração rompe a dicotomia público/privado, reafirma a dignidade da pessoa humana, pois envolve os indivíduos na maior intervenção nas decisões do Estado, especialmente aquelas relacionadas com a qualidade de vida, minimizando as injustiças e intentando promover uma substancial igualdade no seio da sociedade.

Ainda, ao lado, pode-se visualizar o princípio de conservação ou manutenção do status quo (Prinzip der Status-quo-Erhaltung), como também o importante princípio de proteção da continuidade ou da existência (Bestandsschutzprinzip), ou ainda, o princípio de proibição da deterioração (Verschlechterungsverbot). ${ }^{32}$ Todos, de algum modo, são expressões do princípio da proibição de retrocesso. Objetivam uma proibição de retrogradar (ou de "evolução reacionária" no dizer de Canotilho) das condições ambientais conquistadas.

Esses princípios tornam possíveis as condições de um mínimo existencial ecológico, desde uma perspectiva dos princípios da dignidade do humano e da 31 Cf. KLOEPFER, M., Grundprinzipien..., p. 13-14; Umweltrecht..., p. 204 e s.

32 Cf. KLOEPFER, M., Grundprinzipien..., p. 3; Umweltrecht..., p. 169 
segurança jurídica. José Joaquim Gomes Canotilho assim formula uma concepção do princípio de proibição do retrocesso:

[...] o núcleo essencial dos direitos sociaisjá realizado e efectivado através de medidas legislativas (...) deve considerar-se constitucionalmente garantido sendo inconstitucionais quaisquer medidas estaduais que, sem a criação de outros esquemas alternativos ou compensatórios, se traduzam na prática numa 'anulação', 'revogação' ou 'aniquilação' pura e simples desse núcleo essencial. A liberdade de conformação do legislador e a inerente auto-reversibilidade têm como limite o núcleo essencial já realizado ${ }^{33}$.

Portanto, em sede de direitos fundamentais, a proibição do retrocesso social (no caso socioambiental) vincula o legislador infraconstitucional ao poder originário revelador da Constituição, não podendo retroceder em direitos fundamentais efetivados.

Contudo, observe-se, este princípio não é absoluto, protege apenas o que se considera como "núcleo essencial", vale dizer, a "fronteira que o legislador não pode ultrapassar, delimitando o espaço que não pode ser invadido por uma lei sob o risco de ser declarada inconstitucional"34, fronteira esta que não pode ser violada. Ingo Wolfgang Sarlet já anotou que a proibição de determinadas alterações do texto constitucional objetiva o futuro, já que o a Constituição se projeta nele, num exercício proléptico inarredável. Logo, a imposição de limites, pois, impõe-se em defesa da própria Carta Magna ${ }^{35}$.

\section{A RACIONALIDADE ECOLÓGICA E O INTENTO DE UMA FORMULAÇÃO TEÓRICA DOS DEVERES FUNDAMENTAIS SOCIOAMBIENTAIS}

Pensa-se em um modelo de racionalidade ecológica, desde uma perspectiva ecocêntrica moderada ${ }^{36}$, com o objetivo de construir uma crítica jurídico-

33 CANOTILHO, J. J. G., Direito Constitucional e Teoria da Constituição. 2. ed. Coimbra: Almedina, 1.998 , p. 320 e 321.

34 D’ÁVILA LOPES, A. M., Os Direitos Fundamentais como Limites ao Poder de Legislar. Porto Alegre: Sergio Antonio Fabris, 2.001, p. 188

35 A Eficácia dos Direitos Fundamentais. 10. ed. Porto Alegre: Livraria do Advogado, 2010.

36 Uma perspectiva ecocêntrica moderada não refuta um antropologismo de meios, empregando-se aqui 
ambientalista. Neste passo, entende-se por racionalidade ecológica todo o exercício da razão que privilegia as formas impuras e periféricas do pensamento ${ }^{37}$, desde formas argumentativas, empíricas e procedimentos indutivos para a indagação e compreensão da realidade socioambiental, privilegiando a intuição e a emoção, identificando-a com a relação substantiva natureza/cultura, imanente em todo o vínculo presencial biótico/abiótico.

Perceber-se-á, assim, que uma racionalidade ecológica está, na verdade, integrada por muitas visões mesológicas: uma ecologia que pode aceder ao irracional ${ }^{38 ;}$, uma ecologia dos saberes, científicos ou não científicos, dos tradicionais, mesmo daqueles emergentes de crenças e práticas ancestrais; uma ecologia da relação natureza e cultura e da relação adjetivada: natural e cultural; uma ecologia da religião, da estética, da ética, da política, da economia, do direito e da ciência; uma ecologia global, regional, local; uma ecologia urbana, rural; uma ecologia do indivíduo, do gremial, do social; uma ecologia energética, industrial, comercial e incrustada nos serviços de qualquer tipo; uma ecologia humana, interior e que privilegia o alter; uma ecologia profunda, transpessoal e com aguda consciência holística. Uma racionalidade ecológica deste tipo aposta na convivência harmônica com a natureza, intenta por todos os meios preservar as espécies (ameaçadas ou não), já que essas são valorações humanas.

De outro modo, ninguém mais duvida da grave crise ecológica que põe em sério risco o agora frágil equilíbrio natural e cultural de todas as formas bióticas

antropologismo, não como o faz o materialismo que considera o homem apenas como uma parte da natureza, sendo dela um produto; não, o que se pretende com a expressão antropologismo de meios é significar os meios racionais do homem ao perceber a realidade que pode compreender; assim, um antropologismo de meios, não supõe um antropocentrismo de resultados, antes, afirma uma holovisão do mundo da natureza e da cultura.

37 Uma razão que privilegia as formas impuras e as periféricas do pensamento revela um compromisso de aprender a apreender, penetrar na dimensão estética e na dimensão paidética do pensar e do agir, com a possibilidade singular de desenvolver a passagem do pensamento linear ao pensamento sistêmico e complexo por intermédio do uso de recursos expressivos que nos fornece a razão sensível, vale dizer, a capacidade humana em captar e representar as formas cognitivas da realidade, desde uma proporção que reconheça similitudes e diferenças, diria Aristóteles, à percepção que nós percepcionamos - atualidade do sensível e do sensitivo (cf. ARISTÓTELES. Del Alma, 425b, In: Obras Completas. 2. ed. Madrid: Aguilar, 1967, p. 860).

38 Atente-se, na realidade não há o racional e o irracional fora do conhecimento, pois como dizia Pontes de Miranda, "a irracionalidade já é conhecer, e há caminhos para conhecer-se o irracional como tal: o que não conhecemos é o conteúdo, digamos, do irracional, mas por vezes e provavelmente sempre é o que ocorre com o nosso conhecimento" (O problema fundamental do conhecimento. 2. ed. Rio de Janeiro: Editor Borsoi, 1972, p. 93). 
e abióticas ${ }^{39}$, fato que afirma a necessidade de uma racionalidade ecológica consequente. Atente-se, ainda, que uma racionalidade ecológica, ainda que se dirija numa perspectiva ecocêntrica, não repudia o antropocentrismo e o antropomorfismo para fazer sua a defesa da diversidade no seu mais amplo sentido. Ademais, uma racionalidade ecológica privilegia o fator humano revelado pela "dignidade" emprestada ao ser humano, valor este que se estende a todas as coisas e as criaturas vivas, pois todas estão presentes no humano do $\operatorname{ser}^{40}$.

Uma racionalidade ecológica, por preocupar-se em manter contrabalançada a relação biótico/abiótico, desde uma substantiva relação integral natureza/ cultura, compromete-se com as futuras gerações ameaçadas com uma funesta herança, consistente em receber um planeta inabitável pela agressão sistemática ao ambiente: envenenamento da biosfera com suas consequências, desequilíbrios climáticos e efeito estufa, deterioração da camada de ozônio, desflorestamento, contaminação das águas, extinção de espécies vivas, desorganização urbana, enfim, um entorno depreciado à vida em qualquer de suas manifestações.

Uma razão ecológica moderna está na perspectiva do agrupamento dos organismos que processam ou consumem energia, classificados pela sua forma de alimentação, caracterizando-se em níveis tróficos, com os "produtores" ou

39 E aqui não se fala dos riscos produzidos pela probabilidade de perigo criada pelo "imaginário" individual ou social.

40 Por fator humano se entende a multiplicação do que é próprio do ser no jogo humano na perspectiva de Gadamer (La actualidad de lo bello. El arte como juego, símbolo y fiesta. Barcelona: Paidós, 1977, p. 66-68 - a lição de Gadamer vem a calhar, pois o "jogo" veste um símbolo de universalidade, pois associa as noções de regra, liberdade e totalidade, qualquer que seja a ordem destes termos, e ao mesmo tempo se substitui um estado anárquico, por um estado de ordem, metaforicamente se pode dizer que vincula um estado de natureza a um estado de cultura, ou de um estado espontâneo para um estado de ordem. Talvez a ideia mais importante de Gadamer nesta obra seja a de que não se pode pensar o cultural humano sem se pensar no lúdico. De outro modo, por meio do "jogo", encontra-se uma história do "movimento", um automovimento, como diz Gadamer, que se revela no "jogo" e na "arte". Ademais, Gadamer ensina que, na prática humana, o "jogo" inclui a "razão" dado que o homem, disciplina e ordena seus próprios movimentos, "como se tivessem fins", diz ele; isto é, uma racionalidade livre de fins. No "jogo" - afirma Gadamer - se exige um "jogar com..." numa manifestação comunicativa), vale dizer, um jogo que pode incluir em si mesmo a razão, o caráter distintivo mais próprio do ser humano, consistente em darem-se fins e aspirar a eles conscientemente, e poder ironizar o característico da razão. Pois a humanidade do jogo humano tem sede em que esse jogo de movimentos ordena e disciplina, por dizer assim, seus próprios movimentos; movimentos esses expletivos na combinação de dois outros fatores, o abiótico e o biótico, o primeiro, representando os agentes físicos, químicos, geológicos, etc., do ambiente; o segundo, relativo a cada um dos seres vivos da ecosfera; ademais, o fator humano revela-se num processo cujos pressupostos físicos, bioquímicos e fisiológicos vão integrar mecanismos que estão na base de um processo histórico e cultural, este essencialíssimo do homem e da mulher, não encontrado em qualquer outro ser vivo. 
"autrofos" na base do sistema, vale dizer, plantas verdes (terrestres ou aquáticas) das quais deriva, ultima ratio, toda a energia para os demais organismos. Portanto, neste modelo se encontram os herbívoros que consomem os produtores, predadores que se alimentam dos herbívoros e os predadores que consomem outros predadores (cadeia de alimentação).

Nos anos setenta, a razão ecológica, na perspectiva sociológica, passa a ser investigada por meio do que se denominou de "estudos de impacto". Seu mais ilustre representante, Allan Schnaiberg, desenhou uma importante teoria sociológica sobre análise energética e escasse $z^{41}$.

Dos anos oitenta em diante, desenha-se, especialmente frente à realidade da globalização, a tese sociológica da "sociedade risco" com os consequentes problemas ecológicos derivados. Seus expoentes máximos são Ulrich Beck ${ }^{42}$ na Alemanha e Anthony Giddens ${ }^{43}$ na Inglaterra.

Em síntese apertada da obra desses autores, pode-se dizer que, em primeiro lugar, eles descrevem as características e as implicações derivadas dos novos riscos (e perigos também) produzidos pelos processos de modernização e procedimentos de industrialização, fatores que conduzem à sociedade de risco; em segundo lugar, analisam os efeitos desses, numa sociedade em que a incerteza e a insegurança se manifestam desde uma "modernização reflexiva". Este processo, por sua vez, gera uma crise de identidade pessoal pela individualização de muitas esferas da vida cotidiana, incluindo a família e o trabalho; e, finalmente, de posse dessa análise, estudam o papel ambíguo da ciência e a sua influência na formatação de novos espaços e estratégias políticas.

$\mathrm{Na}$ atualidade se aposta numa racionalidade ecológica, cosmocêntrica, impura e periférica. Quando se refere ao impuro e ao periférico, quer se referir a um estado que nega o "puro", vale dizer, algo situado num espaço enclausurado e não contextual e atomizado, inversamente, o "impuro" está contextualizado, assume posições, vínculos e relatos, tudo isto gera uma "pluralidade" que produz diferentes (dis)posições e conteúdos que se ampliam em "novas narrativas"

41 SCHNAIBERG, A. The environment: From surplus to scarcity. Oxford: Oxford University Press,1975.

42 BECK, U. The risk Society. London: Sage, 1992.

43 GIDDENS, A. Consecuencias de la modernidad. Madrid: Alianza Ed., 1993. 
cronotopicamente localizadas que predicam a historicidade do processo.

Aposta-se na periferia tendo em consideração que "centro" só há um, caso se aceite que tudo está relacionado, ademais, uma "visão da periferia" força por refletir que "não se está num entorno", como se ele fosse "algo alheio" a nós mesmos. Não! Não se está no entorno, "Nós somos o entorno"! Pensar uma razão ecológica conduz à interdisciplinaridade de todos os campos dos saberes, ampliando e desenvolvendo as disciplinas existentes e propondo, por meio delas, e do patrimônio cultural periférico, novos contextos, para que o núcleo interdisciplinar se enriqueça e atenda a todos, neste "lugar de encontro" que é o ambiente.

Por certo, o direito moderno, no paradigma do Estado Democrático de Direito, esgota-se na formalidade legalista e positivista do ordenamento jurídico estatal. Tal circunstância aponta, desde logo, a sua limitação para a resolução dos problemas e conflitos gerados no âmbito socioambiental, seja no nível institucional do poder judiciário, seja no nível da legislação positiva estatal. A ideologia liberal-capitalista (encerrada no princípio da acumulação e seu corolário da eficiência) que sustenta esse paradigma acredita num tipo de democracia exclusivamente representativa, do mesmo modo, credita à cidadania apenas o poder de representação, assegurando aos indivíduos direitos abstratamente considerados.

Por isso, pensa-se num Estado Socioambiental e Democrático de Direito - numa perspectiva de inclusão das necessidades sociais e ambientais -, do qual flui a emergência de um novo sentido de cidadania, que aponta para uma democracia socioambiental fundada em direitos e deveres concretos, na participação real e consciente dos indivíduos singulares e plurais, conformando uma ecocidadania responsável em assegurar as condições que possibilitem afirmar que um mínimo existencial ecológico, núcleo material do princípio da dignidade humana, deve ser um máximo de concretização dos direitos fundamentais.

$\mathrm{Na}$ verdade, uma porta aberta para a regulação e garantia das conquistas sociais, enfim, uma afirmação consciente da supremacia do princípio da dignidade humana, induzindo à concretização de um direito fundamental à segurança que este Estado de Ambiente deve produzir para as presentes e futuras gerações, 
entendendo, esta última, como um dos resultados da garantia de regulação eficaz que atenda à supremacia dos interesses constitucionalmente albergados; de modo especial, o princípio da dignidade da pessoa humana, que só se realiza com a proteção de um mínimo existencial ecológico, forte na vedação da degradação ambiental. Uma razão assim articulada, não pode ser refutada.

O emérito e saudoso professor da Universidade de São Paulo (USP), Gofredo da Silva Teles Júnior (nome como ele mesmo adotou), afirmava que ter direitos é ter, evidentemente, as obrigações correspondentes aos direitos dos outros ${ }^{44}$; contudo, não é só isso. Ter deveres é condição para o próprio sujeito (que deve) conservar os direitos e, não se está tratando aqui da noção de direitos-função (a que se refere à dogmática jurídica) ${ }^{45}$; de outro modo, não se está tratando daquelas cadeias do pensamento jurídico que afirmam a unidade do direito (em sentido objetivo-subjetivo) ${ }^{46}$; prefere-se conceber o dever como uma atribuição de necessidade, necessitas moralis, como já afirmara há muito Leibniz ${ }^{47}$, correlativo do direito, que é atribuição de poder, potentia moralis e subsume o binário do justo/injusto, do legal/ilegal, etc.

O dever está travado na valoração desde uma permissão (ser) que exige cumprimento (dever-ser). De outro modo, reveste uma realidade do cultural, pois o direito/dever está dirigido ao valor da segurança e da justiça, num exercício derivado das relações de fraternidade, objetivando realizar a máxima vantagem social (ou o bem comum ${ }^{48}$ ). Está em nós mesmos (portanto, está no sujeito), por 44 TELLES JUNIOR, G. Iniciação na ciência do direito. São Paulo: Saraiva, 2001, p. 273.

45 Onde o sujeito tem a permissão e ao mesmo tempo o dever, como no caso específico dos funcionários públicos.

46 Como é o caso da teoria pura do direito de Kelsen, ou a teoría egológica del derecho de Cossio. A teoria pura destaca a norma, fazendo depender o direito subjetivo do objetivo, e a teoria egológica arrazoa, fundamentalmente, sobre a conduta, isto é, o direito subjetivo (faculdade e dever jurídico e não o direito subjetivo em sentido estrito), só que reconhece ser direito objetivo e subjetivo, termos logicamente correlativos (cf. BATALHA, Wilson de Souza Campos, Nova introdução ao direito. Rio de Janeiro: Editora Forense2000, p. 526)

47 Gottfried Wilhelm Leibniz (1646 - 1716), definia o direito como "potentia moralis" ou ainda, como "facultas seu moralis potentia": "Qualitas realis [moralis?] in ordinem ad actionem duplex est: potentia agendi et necessitas agendi; ita potentia moralis dicitur Jus, necessitas moralis dicitur Obligatio" ("A qualidade real (moral?) ordenada à ação é dupla: potência de agir e necessidade de agir; assim, a potência moral se chama direito, a necessidade moral, obrigação"), isto está em Fragmento sem título, in: Textes inédits, tomo II, Grua, Gastón ed., París, 1948,p. 811; obra consultada na Biblioteca Central de Universidade de Coimbra (2003). Em Spinoza, potentia moralis, melhor se expressaria com potestas moralis

48 Que nada tem a ver com a doutrina da supremacia do interesse público sobre o interesse privado. Ao contrário, realizar o bem comum, ou a máxima vantagem social, é concretizar a supremacia do inte- 
isso, está no sentimento que o direito envolve uma identidade em um sistema binário: justo-injusto, legal-ilegal, permitido-proibido, adimplido-inadimplido.

Está em nós mesmos, já que todo direito pressupõe liberdade, mas ausente o "dever" (e.g., o dever de não interditar), não há liberdade possível. Assim, só entendida como resultado de direitos e deveres, equitativamente pensados (resultado de uma noção política-jurídica equilibrada), a liberdade alcança a Justiça ${ }^{49}$. Contudo, assinale-se que o direito justo ou injusto é direito (desde que inserido num sistema jurídico existente, válido e eficaz), já o direito e o dever desequilibrados não; isso porque o ideal que o equilíbrio busca alcançar é o ideal de Justiça (e não se está falando de uma justiça metafísica, mas de uma Justiça como uma câmara de compensações cujos direitos e deveres sejam os títulos ${ }^{50}$ ).

resse social (popular) ou interesse público primário, materializado na sua constituição, que reside em participação sociopolítica fraterna, desde mecanismos de conscientização para a ação que deverá ser desenvolvida numa praxis social que irá confrontar as diversas ideologias dos grupos sociais num ciclo dialético permanente.

49 Justiça como adequada prestação jurisdicional conforme ao Direito.

50 Sim, pode-se pensar a Justiça como uma câmara de compensações (a semelhança de uma Verrechnungsstelle, ou em inglês: Clearing House) dos títulos inscritos como direitos e deveres. Quase sempre a Justiça está obscurecida, convenientemente, por aqueles que podem manipular o poder comunicativo social, mas eles olvidam da grandeza do poder do ser a que bem se referiu o grande Walt Whintman: I am an acme of things accomplished / And I am an enclosure of things to be (Apud, PROGOFF, I. Depth Psychology and Modern Man, New York: The Julian Press Inc., 1959, p. 90: Sou um ápice de coisas realizadas / E sou um [espaço] cercado de coisas que são). Daí que o simbolismo da Justiça acentua, sistematicamente, uma união harmoniosa de forças opostas; os pratos da balança não pesarão olho contra olho, e não distribuirão a recompensa e o castigo. As complexidades do ser humano não podem ser assim, mecanicamente, determinadas. A espada da Justiça não está aí para ferir os perversos, ou para agradar os virtuosos, seu símbolo é maior, está implicado a reconciliarmos em um mundo em que os trapaceiros parecem prosperar e os inocentes acabam em um monte de esterco. De outro lado, Jó não foi o primeiro e certamente não será o último a lastimar-se desse estado de coisas, mas seguirá sempre determinado que, ao fim e ao cabo, a Justiça triunfará. Os dois pratos da balança da justiça permanecem vazios, prontos para aceitar e receber a dualidade humana. Somente depois que aceitarmos a complexidade de nossa natureza seremos capazes de abordá-la e compreendê-la. Os místicos vêm nos pratos o número oito, também o signo do infinito $[\infty]$, os dois círculos do "oito" perpassados por dois eixos, um superior, o vertical (celeste), outro inferior, o horizontal (terreno), que lhe dá equilíbrio. A Justiça, assim, é mediadora de duas realidades, não mira nem a balança nem a espada, sua visão é interior, e sua venda está ali para que não se confunda com o detalhe e a parcialidade pessoal. Nossos tribunais de justiça mantêm um equilíbrio de trabalho entre o indivíduo e o Estado, e entre um indivíduo e outro. A solução legal não é determinada por uma régua de cálculo. O querelador que vence uma ação judicial nunca recuperará exatamente o que perdeu, seja a saúde, os bens materiais, o tempo precioso ou o nome honrado. O tribunal só pode adjudicar-lhe uma compensação. A natureza, igualmente, oferece compensações, ainda que aí, também, nunca se recupera exatamente o que se perdeu, v.g., quando se debilita um sentido, os demais se tornam mais aguçados. O que quer que se ganhe nunca é idêntico ao que se perde, nem se poderá dizer que seja, precisamente, o oposto, mas, de um modo especial, compensa a perda da capacidade debilitada. Os tribunais são instrumentos úteis para conseguir certos tipos de compensação e equilíbrio social (Cf. PEREIRA DA CÂMARA, A., O valor Justiça, manifestação, no plano social, da vontade criadora e redentora de Deus, in: AJURIS, n.o 6, Porto Alegre, 1976. 
Em nosso entendimento os direitos e os deveres equilibrados estão no mundo cultural sobreposto ao natural, em uma relação de dependência factual. Por isso, estão incorporados em uma ação (ou estrutura) de relevância social (pois a ideiavalor que o social Ihes implica não é arbitrária); ainda mais, é a força que deve subordinar-se ao direito, todavia, é evidente que somente numa sociedade ficta, o direito dispensaria a força, o respeito devido seria autógeno ${ }^{51}$.

De qualquer forma, direitos e deveres equilibrados servem como instrumentos de resistência, pois eles, nesta situação, articulam uma especial forma de ser e de dever-ser, isto é, do fático e do normativo (natural/cultural), da realidade e da normatividade, o que leva a juridicidade que é sempre articulação da normatividade e da realidade, como bem afirmou Baptista Machado:

[...] é certo por um lado que o conteúdo normativo-valorativo do Direito não depende da eficácia (vigência social); mas, por outro lado, também o é que os valores ideais só são jurídicos-positivos, só têm juridicidade, quando se institucionalizam na ordem social real vigente ${ }^{52}$.

\section{CONSIDERAÇÕES FINAIS: UMA DEONTOLOGIA SOCIOAMBIENTAL}

Lançar as bases para a formulação de uma reflexão sobre os deveres fundamentais socioambientais, com a preocupação de desenhar um Estatuto Deontológico dos Direitos e Deveres Fundamentais Socioambientais, é um empreendimento que requer muito esforço.

Sabe-se que deontologia etimologicamente significa ciência do dever, está

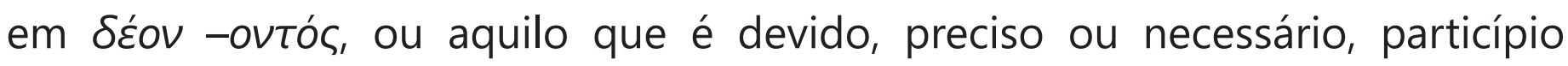
presente neutro de $\delta \varepsilon \omega^{53}$, logo, vai-se entender a expressão como aquilo que é necessário, conveniente. Contudo, não se esquece de que a criação do termo é de Benthan (Deontology or the science of morality, 1834), e depois foi empregado pelos utilitaristas para designar o estudo empírico que se necessita fazer em uma situação determinada. Com o passar do tempo o uso do termo foi apropriado

51 Do grigo autoyvés - autogenés, isto é, que se gera a si mesmo.

52 BAPTISTA MACHADO, J. Introdução ao Direito e ao discurso legitimador. Coimbra: Livraria Almedina, 1999, p. 42

53 Que é obrigar, mas, antes, ter falta ou estar necessitado de algo, também desejar, pretender. 
pelas associações profissionais para construir um catálogo de deveres vinculados à praxis profissional.

A origem da necessária apropriação está na dissimetria ocasionada por alguns detentores do conhecimento e da técnica que lhes outorgou um grande poder, e o usuário deste saber e técnica ficou reduzido a uma dependência intelectual e econômica. Logo os códigos intentaram superar essa dissimetria com regras formais cuja transgressão é passível de sanção.

O intento de refletir sobre os deveres fundamentais socioambientais está intimamente vinculado ao desenho de uma Deontologia Socioambiental, e por consequência, não pode afastar-se do indispensável estudo da Moral, na perspectiva de uma Moral Pública ${ }^{54}$. Neste sentido, a deontologia possui um viés moral.

Os deveres morais frequentemente denominam-se deontológicos. Há uma deontologia moral, sem dúvida, assim como há uma deontologia jurídica em sentido estrito. O que mais interessa é a deontologia jurídica, na qual estão contidos os deveres jurídicos de qualquer tipo. Atente-se que, mesmo nos códigos de ética profissional, a parte dispositiva sobre os deveres é jurídica, pois os atos de coerção previstos não são unicamente aprovados pela consciência, mas são atos coercitivos socialmente organizados que têm efeitos no próprio grupo profissional, levando inclusive a interdição da profissão (!) e com efeitos na ordem jurídica estabelecida.

Com maior razão, a construção de uma deontologia socioambiental, fundada na moral pública, mas com forte densidade jurídica, é uma exigência para a maior eficácia dos direitos fundamentais socioambientais que todos, Estados e particulares, devem privilegiar.

54 Cf., em particular, Joseph Raz, The Morality of Freedom, Oxford: Clarendon Press, 1979 (especialmente p. 37-52; 212-220). Também, About Morality and the Nature of Law, em: The American Journal of Jurisprudence 48 (2003) 1-15. Ainda, The authority of Law: Essays on Law and Morality. Oxford: Oxford University Press, 2002. Observe-se que, para Raz, o que determina a validez das regras de direito são suas fontes jurídicas, portanto, ainda que o fenômeno jurídico, como tal, resulte de fatos sociais e estes de alguma forma vinculem conteúdos morais, tal circunstância não autoriza a incorporação da moral no direito, pois a validade da norma está indelevelmente presa a sua fonte (jurídica), e esta última não vincula um conteúdo moral. Daí a formulação da sua strong social thesis, pois a validade das normas jurídicas depende apenas de fatores empíricos, de fatos sociais, livres, portanto, de critérios de justiça ou de correção moral (The authority of Law: Essays on Law and Morality. Oxford: Oxford University Press, 2002. pp. 39-40; também 228 e segs.). 
Portanto, a deontologia jurídica no âmbito ambiental deve intentar desenhar uma deontologia socioambiental que construa e identifique os deveres fundamentais socioambientais distintos das obrigações socioambientais. Daí o necessário enfoque da distinção entre deveres, obrigações, ônus, sujeições e encargos socioambientais, privilegiando sempre a fundamentalidade dos deveres e das responsabilidades inerentes ao próprio conceito dos Direitos e dos Deveres Fundamentais. Neste sentido, foi feliz a Declaração de Responsabilidade e Deveres Humanos de Valença de 1999, pois os deveres estão na base da efetiva validez dos direitos humanos e fundamentais.

Por conseguinte, necessário investigar com apuro e com o intento de sistematizar os deveres dedicados à proteção do ambiente e da biodiversidade, além do dever de informar todas aquelas atividades que possam afetar o meio ambiente, ademais do dever de restaurar ou ressarcir os danos eventualmente ocasionados, deveres esses que cabem tanto ao Estado como aos particulares, que devem ter presente todos os recursos naturais, renováveis e não renováveis, incluídos a biodiversidade biológica (flora e fauna); o solo; o subsolo; o espaço aéreo; o espectro eletromagnético; os recursos hídricos, hidrocarburos, minerais; pedras preciosas ou semipreciosas e outros compostos e elementos que se encontram de forma natural na terra, dentro dos limites do território nacional; tendo em vista a conservação e o manejo das áreas protegidas e os sítios de importância biológica, paleontológica, histórica, cultural, arqueológica, espeleológica, geológica e as paisagens de excepcionais características.

De outro modo, tal empresa deverá identificar e sistematizar o dever do Estado na regulação e no controle no ingresso e na saída do país de recursos biológicos e genéticos, e sua utilização de acordo com os interesses nacionais, somando-se o dever do Estado e da Sociedade na proteção do acervo natural e do seu aproveitamento sustentável para a garantia de sua conservação, até mesmo como recurso estratégico, para as atuais e futuras gerações.

Direitos, deveres, pretensões, obrigações, ações e exceções, a célebre sena pontiana, conjunto de seis categorias que ocorrem no espaçojurídico, são produtos culturais. Direitos e Deveres como categorias jurídicas implicam atribuições para 
sujeitos identificados ou identificáveis em algum cronotopo definido ou definível. Sujeitos de direitos e deveres são as pessoas naturais ou fictas, as universalidades de direito e as instituições e os órgãos despersonalizados.

Partir de uma consideração deontológica dos direitos fundamentais socioambientais revela uma conexão íntima com deveres que a todos são impostos em relação com a natureza, com o biótico e abiótico, motivo pelo qual se assumem obrigações (correlativas às pretensões) de evitar a degradação sistemática do espaço socioambiental.

Como sujeitos de direitos, de alguma forma, todos estão submetidos às leis naturais (e aos mandamentos culturais) a que se submete o planeta, especialmente os humanos. Como espécie, somos como qualquer outra espécie, e os deveres de proteção são da espécie, não da natureza. Os sistemas naturais, a natureza, dispõem de processos de proteção frente à ação antrópica ${ }^{55}$. Basta, para tanto, destruir a espécie, não há qualquer segurança transcendente para a proteção aos seres humanos que degradam o espaço que ocupam e onde atuam, portanto, esta é uma razão suficiente para uma autoimposição de deveres de preservar e promover as condições de vida planetária. Os recursos naturais são limitados, as reservas não são intermináveis e acabarão por esgotar-se, não se pode esperar que uma tecnologia viesse no futuro sanar os problemas que no presente são quase incontornáveis.

Como sujeitos de direitos, somos também obrigados a atuar de modo responsável. Neste sentido, tem-se o dever de se solidarizar, primeiro, com os processos naturais, em estrita cooperação com eles, só assim se poderão construir os instrumentos necessários para a nossa sobrevivência como espécie. Atente-se que os intercâmbios bióticos e abióticos não se comportam de modo singelo e linear, mas sim de modo complexo plurilinear, isto é, tudo está em interação e em mútua dependência: o que ocorra em um determinado lugar do planeta repercutirá em outra ambiência ou em uma determinada espécie, pois esta mútua interação e dependência asseguram - ainda que de modo paradoxal - a biodiversidade.

Contudo, essa interação e essa biodiversidade ocorrem em uma larga escala temporal que necessariamente não coincide com o timing da produtividade 55 O adjetivo antrópico é qualificador da ação do homem relativamente às transformações por ele provocadas no ambiente. 
alocada e inconsciente que exigem as sociedades de consumo indiscriminado, sirva de exemplo o denominado aquecimento global, que conduz ao dano atmosférico irreversível dado ao progredimento rápido e continuamente crescente da escala temporal em que os processos naturais atuam em sua reprodução ${ }^{56}$. Observese que se as interações humanas respeitassem a biodiversidade, incluídas nesta ambiência as relações sociais, os mecanismos de regulação entre os qualificados e diversificados elementos dos sistemas naturais estariam assegurados. Todavia, a intervenção antrópica homogeneizante e preocupada exclusivamente pelo benefício econômico imediato modificou substancialmente a velocidade, a simetria e os equilíbrios entre tais processos.

É sabido que uma floresta, em sua escala temporal, filtra os elementos daninhos à sua manutenção; contudo, quando a ação antrópica é que "filtra" rápida e continuamente, por lavradores ou madeireiros, esses processos naturais se fragmentam e desaparecem. Portanto, uma deontologia socioambiental tem por objetivo afirmar o dever de proteger e promover a sustentabilidade ambiental e social em todas as relações que se estabelece com o biótico e abiótico; ademais, tem o dever de precaução ante as incertezas e a falta de previsão das consequências sociais e naturais das políticas econômicas e ambientais do atual modo de produção, um modelo já convertido na forma globalizada de justificar, decodificar e interferir no mundo.

Discorrer sobre direitos e deveres, na perspectiva jurídica - abandonando propositadamente os denominados moral rights e os respectivos moral duties, ainda que possam, como efetivamente assim ocorre, influir como razões justificatórias dos 56 As emissões de gases de efeito estufa, v.g., dióxido de carbono ( $\mathrm{CO} 2)$, metano $(\mathrm{CH} 4)$, e óxido nitroso (N2O), além dos clorados e fluorados dos hidrocarbonetos (CFC), produzem significativo mudança climática, o que tem gerado uma imensa dívida ambiental, a denominada dívida do carbono. Esta dívida que deveria ser paga pelos que mais contaminam passa a ser através da "razão astuta" um ótimo negócio; aliás, desde os anos setenta uma "razão astuta" tem sido sustentada teoricamente pelos seguidores do movimento do Law and Economics, na denominada escola de análise econômica do direito, na esteira de Ronald Coase, Guido Calabresi, Richard A. Posner, Kenneth Arrow, entre outros. Atente-se que os juristas imbricados aos postulados do Law and Economics acreditam na análise econômica, seja instrumental e funcional, perseguindo uma evolução formal do direito. Mas, na verdade, esta teoria se associa a uma versão pragmatista do direito com forte acento na crença de um direito flexível e intuitivo. Contudo, a análise econômica do direito, suportada num determinismo de tipo científico, aponta soluções ambivalentes e indeterminadas mais próximas dos interesses crematísticos da economia moderna. Certamente, está-se gerando uma dívida ecológica para com as gerações futuras que, evidentemente, não se vai poder pagar; vale dizer, está-se vivendo do "crédito ecológico", com a tranquilidade de saber que nunca se vai quitar essa dívida, sequer os seus "juros". 
direitos e dos deveres jurídicos -, pode levar a equívocos entre as relações que se estabelecem entre autoridade e liberdade como característica dos regimes políticos. Em sede política, é comum que ao privilegiar-se a autoridade seja atribuído aos deveres a maior significância na ordem jurídica; ao contrário, sempre que privilegiada a liberdade, o destaque vai para o conjunto de direitos atribuídos pelo ordenamento jurídico. Ao lado, discorrer sobre deveres fundamentais, na perspectiva jurídica, pode, também, levar a alguns equívocos na distinção entre deveres e obrigações, entre deveres constitucionais e entre estes os deveres fundamentais, e deveres legais, entre obrigações constitucionais e obrigações legais.

Neste artigo, desprezam-se deliberadamente, ainda que importantes, as considerações históricas da inserção dos deveres nas Constituições, assim como, do mesmo modo, não se referiu às características analíticas dos deveres na perspectiva modal, portanto se simplificou a aproximação a eles desde uma única perspectiva: a de posições jurídicas subjetivas em sentido amplo no espaço do jurígeno ${ }^{57}$, seja na esfera social de sujeitos singulares ou plurais, seja na esfera do Estado e suas extensões.

Toda produção do direito está impregnada pelas significações de disposição e posição. Com estes termos se quer denominar:

(a) a produção das normas de permanência temporal e integração no sistema jurídico constituído e dominado por disposições de naturezas diversas, entre elas, veja-se o caso do denominado direito objetivo, dispondo sobre os modos e meios de adaptação e corrigenda das relações inter-humanas no espaço/tempo social; e,

(b) a atribuição e individuação de posições jurídicas subjetivas positivas ou negativas ou intersubjetivas, como o caso dos denominados direitos subjetivos (ou a subjetivação do direito objetivo) ou dos deveres jurídicos (positivos ou negativos, como correlatos dos direitos, ou autônomos).

No que toca às posições subjetivas, podem estas ser qualificadas como ativas, passivas, ou mistas, segundo especiais condições conferidas ao sujeito. As posições jurídicas passivas, que nos interessaram, no momento, são aquelas denominadas

57 Aqui se utilizou a expressão espaço jurígeno para identificar aquela fração do espaço sociocultural em que é produzido o direito. 
de deveres-obrigações, e entre estas, os deveres fundamentais. Neste sentido convém, num primeiro momento, pensar os deveres, em sentido amplo, como posições assertórias de determinado comportamento, isto é, o comportamento devido e as obrigações refletem o lado passivo das relações jurídicas, como há muito já o afirmava Couture ${ }^{58}$, em que um sujeito está compelido a fazer ou omitir alguma coisa em relação a outro. Portanto, enquanto um comportamento devido tem por pressuposto uma abstenção de qualquer interdição na fruição de um direito, um comportamento obrigatório cuida por satisfazer o direito correlativo mediante o exercício de ações ou omissões dedicadas.

Nem todas as posições passivas são deveres, no sentido estrito; e nem todas as posições ativas, direitos subjetivos como com acuidade afirmava Pontes de Miranda ${ }^{59}$. Os exemplos que se trazem, segue o pontiano, são de "interesse legítimo", interesse econômico ou moral, com que se pode intentar ação, sem se ser titular de direito subjetivo. Porém o interesse legítimo, em tal caso, é ligado à proteção de direito que seria ofendido com a decisão, ou a que ela aproveitaria, embora não seja a res in iudicium deducta. As principais situações jurídicas, que se procuraram ver como sem sujeito passivo, foram as do direito de propriedade e as dos direitos de personalidade, como se o ser relação jurídica com todos importasse em ser relação jurídica sem o segundo termo ${ }^{60}$. Isto é facilmente compreensível, pois no momento em que há violação, o que está em causa é a ação, e não só o direito.

Na realidade, a regra jurídica é regra para relações inter-humanas, ou, mais exatamente, interpessoais, sendo o conceito de pessoa o conteúdo de uma das regras jurídicas, pois nela há regramento de relação entre as pessoas existentes e as que ela cria. A regra, considerando suficiente o suporte fático, torna-o jurídico; e a relação jurídica estabelece-se entre a nova pessoa e as outras. Onde quer que a regra jurídica crie direitos, do lado passivo, por parte de todos, ou de alguém, está o alterum non laedere. E da natureza das coisas que não se possam criar direitos que se não dirijam a alguém. Nem dever que não tenha do outro lado, a posição subjetiva, ativa, do titular de direito. Dever consigo mesmo seria, apenas,

58 Cf., Eduardo J. Couture. Vocabulário Jurídico, Montevideo, 1960, Vox: deber.

59 Tratado de Direito Privado, tomo V, § 560, 2, p.103 e ss. Rio de Janeiro: Editor Borsói, 1955.

60 Pontes de Miranda, F. C. Tratado de Direito Privado, tomo V, § 560, 2, p.104. Rio de Janeiro: Editor Borsói, 1955. 
dever moral, não dever jurídico ${ }^{61}$.

Em síntese, como já afirmava Pontes de Miranda, dever corresponde a direito; obrigação, pretensão62, logo, os deveres e as obrigações estão identificados ou com o direito subjetivo, ou com os interesses legítimos, e enquanto os deveres pressupõem uma abstenção de perturbação do gozo de um direito, ou na interdição dele, ou no exercício de suas faculdades; as obrigações implicam o exercício indispensável das atividades necessárias para satisfazer os direitos (cumprimento das obrigações) cuja pretensão se manifestou.

\section{REFERÊNCIAS}

ALEXY, Robert. Teoría de los derechos fundamentales. Trad. de Ernesto Garzón Valdés. Madrid: Centro de Estudios Políticos y Constitucionales. 3. ${ }^{\text {a }}$ reimp. 2002.

ARISTÓTELES, Del Alma. 425b. In: Obras Completas. 2. ed. Madrid: Aguilar, 1967.

BAPTISTA MACHADO, J. Introdução ao Direito e ao discurso legitimador. Coimbra: Livraria Almedina, 1999.

BATALHA, Wilson de Souza Campos. Nova introdução ao direito. Rio de Janeiro: Editora Forense, 2000.

BECK, U. The risk Society. London: Sage, 1992.

BENJAMIM, Antônio Herman V., Função ambiental. In: Dano ambiental: prevenção, reparação e repressão. São Paulo: Revista dos Tribunais, 1993.

BENJAMIN, Antônio Herman V. Crimes contra o meio ambiente: uma visão geral. In: Ministério Público e Democracia - Livro de teses. Fortaleza: Conamp, 1998.

CANOTILHO, J. J. G. Direito Constitucional e Teoria da Constituição. 2. ed. Coimbra: Almedina, 1.998.

CANOTILHO, J. J. G. Direito Público do Ambiente. Coimbra: Faculdade de Direito de Coimbra, 1995.

CASALTA NABAIS, José. O Dever Fundamental de Pagar Impostos. Lisboa: Almedina, 2009.

61 Pontes de Miranda, F. C. Tratado de Direito Privado, tomo V § 560, 2, p.104. Rio de Janeiro: Editor Borsói, 1955.

62 Pontes de Miranda, F. C. Tratado de Direito Privado, tomo V, § 607, 3, p. 188, Rio de Janeiro: Editor Borsói, 1955. 
COASE, Ronald. The problem of social cost. In: Journal of law and economics, I-44, outubro de 1960, Univ. of Chicago Press.

COUTURE, Eduardo J. Vocabulário Jurídico. Montevidéu, 1960.

CREIFELDS et all. Rechtswörterbuch. München: Beck, 2007

D'ÁVILA LOPES, A. M., Os Direitos Fundamentais como Limites ao Poder de Legislar. Porto Alegre: Sergio Antonio Fabris, 2.001.

GADAMER. La actualidad de lo bello. El arte como juego, símbolo y fiesta. Barcelona: Paidós, 1977.

GIDDENS, A. Consecuencias de la modernidad. Madrid: Alianza Ed., 1993.

KLOEPFER, Michael. Umweltrecht. 3. ed. Munique: Beck Juristischer Verlag, 2004.

LEIBNIZ, Gottfried Wilhelm. Fragmento sem título. In: Textes inédits, tomo II, Grua, Gastón ed., París, 1948.

LEITE, J. R. M. Dano Ambiental: do individual ao coletivo extrapatrimonial. 2. ed. rev., atual. ampl. São Paulo: Editora Revista dos Tribunais, 2003.

LEITE, José R. Morato; AYALA, Patryck de Araújo. Novas Tendências e Possibilidades do Direito Ambiental no Brasil. In: WOLKMER, Antonio Carlos; LEITE, José Rubens Morato, org. Os Novos Direitos no Brasil: Natureza e Perspectivas. 1. ed. São Paulo: Saraiva, 2003.

MACH, Ernst. Erkenntnis und Irrtum: Skizzen zur Psychologie der Forschung. Leipzig, 1920.

MARTIN MATEO, R. Manual de derecho ambiental. Madrid: Trivium, 1995.

MOLINARO, Carlos Alberto. Pensando a Intervenção Regulatória do Sistema Jurídico nas Fases Iniciais dos Sistemas Tecnológicos em um Estado Socioambiental e Democrático de Direito. In: SILVA, Vasco Pereira da, SARLET, Ingo W. (Org.). Direito Público Sem Fronteiras, Lisboa: Instituto de Ciências Jurídico-Políticas, 2011.

MOLINARO, Carlos Alberto. Interdição da retrogradação ambiental - Reflexões sobre um princípio. In: O Princípio da Proibição do Retrocesso Ambiental, Coletânea da Comissão de Meio Ambiente, Defesa do Consumidor e Fiscalização e Controle do Senado Federal. Brasília: Senado Federal, 2012. 
PEREIRA DA CÂMARA, A. O valor Justiça, manifestação, no plano social, da vontade criadora e redentora de Deus. In: AJURIS, nº 6, Porto Alegre, 1976.

PIGOU, Arthur C. (1932). The Economics of Welfare. London: Macmillan and Co. [ed. orig.: 1920]. Versão eletrônica, http://www.econlib.org/library/NPDBooks/Pigou/pgEWCover.html.

PONTES DE MIRANDA, F. C. Tratado de Direito Privado, tomo V, § 560, 2, p.104. Rio de Janeiro: Editor Borsói, 1955.

PONTES DE MIRANDA, O problema fundamental do conhecimento. 2. ed. Rio de Janeiro: Editor Borsoi, 1972.

PROGOFF, I. Depth Psychology and Modern Man, New York: The Julian Press Inc., 1959.

RAZ, Joseph. The Morality of Freedom. Oxford, Clarendon Press, 1979; About Morality and the Nature of Law, In: The American Journal of Jurisprudence 48 (2003) 1-15. The authority of Law: Essays on Law and Morality. Oxford: Oxford University Press, 2002. pp. 39-40

SARLET, Ingo W. A Eficácia dos Direitos Fundamentais. 10. ed. Porto Alegre: Livraria do Advogado, 2010.

SCHNAIBERG, A., The environment: From surplus to scarcity. Oxford: Oxford University Press, 1975.

SOUZA FILHO, Carlos F. Marés. O dano socioambiental e sua reparação. In: FIGUEIREDO, Guilherme J. Purvin de (Coord.). Direito Ambiental em debate. Rio de Janeiro: Esplanada, 2004.

TELLES JUNIOR, G. Iniciação na ciência do direito. São Paulo: Saraiva, 2001.

Recebido em: mar/2015

Aprovado em: jul/2015 